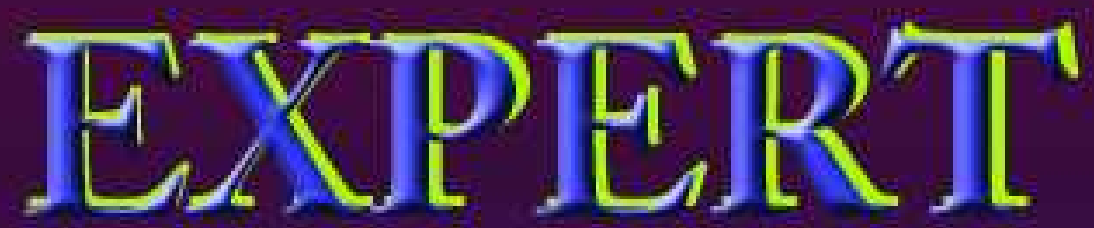

Jurnal Sistem Informasi

PERANCANGAN PROTOTYPE TEKNOLOGI SMART BUILDING MENGGUNAKAN ARDUINO BERBASIS WEB SERVER UNTUK MENDUKUNG PEMBANGUNAN PROPINSI LAMPUNG MENUJU PROGRAM LAMPUNG "SMART CITY"

Budi Usmanto, Tri Susilowati

SISTEM PENDUKUNG KEPUTUSAN PERANGKINGAN SEKOLAH MENENGAH KEJURUAN (SMK) DI KABUPATEN PRINGSEWU MENGGUNAKAN METODE WEIGHTED PRODUCT (WP)

Oktafianto, Elisabet Yunacti Anggracni, Suyono

OTORISASI PENGGUNA LABORATORIUM IBI DARMAJAYA BERBASIS CLIENT SERVER

Hendra Kurniawan, Hermanto

SISTEM PENDUKUNG KEPUTUSAN BERBASIS ANALYTICAL HIERARKHI PROCESS UNTUK PENENTUAN PENGISIAN JABATAN

Fenty Ariani

SEBARAN MENARA TELEKOMUNIKASI SELULER BERSAMA BERBASIS GIS (GEOGRAPHIC INFORMATION SYSTEM)

DI WILAYAH KABUPATEN LAMPUNG TENGAH

Taqwan Thamrin, Wiwin Susanty

AUTHENTIFIKASI LOGIN USER PADA PERANGKAT LUNAK MENGGUNAKAN ARDUINO DAN ENKRIPSI AES 256

Apri Triansah

ISSN : 2088-5555

$$
\text { Write To Be Experte }
$$




\section{Expert}

Jurnal Manajemen Sistem Informasi dan Teknologi

Volume 07, Nomor 02, Desember 2017

\begin{tabular}{|c|c|}
\hline Judul & Hal \\
\hline $\begin{array}{lllr}\text { PERANCANGAN } & \text { PROTOTYPE } & \text { TEKNOLOGI } & \text { SMART } \\
\text { BUILDING } & \text { MENGGUNAKAN ARDUINO BERBASIS WEB } \\
\text { SERVER } & \text { UNTUK } & \text { MENDUKUNG PEMBANGUNAN } \\
\text { PROPINSI LAMPUNG } & \text { MENUJU PROGRAM LAMPUNG } \\
\text { "SMART CITY" } & & & \\
\end{array}$ & $57-65$ \\
\hline $\begin{array}{l}\text { SISTEM PENDUKUNG KEPUTUSAN PERANGKINGAN } \\
\text { SEKOLAH MENENGAH KEJURUAN (SMK) DI KABUPATEN } \\
\text { PRINGSEWU MENGGUNAKAN METODE WEIGHTED } \\
\text { PRODUCT (WP) }\end{array}$ & $66-71$ \\
\hline $\begin{array}{l}\text { OTORISASI } \quad \text { PENGGUNA } \quad \text { LABORATORIUM } \\
\text { DARMAJAYA BERBASIS CLIENT SERVER }\end{array}$ & $72-76$ \\
\hline $\begin{array}{l}\text { SISTEM PENDUKUNG KEPUTUSAN BERBASIS } \\
\text { ANALYTICAL HIERARKHI PROCESS UNTUK PENENTUAN } \\
\text { PENGISIAN JABATAN }\end{array}$ & $77-82$ \\
\hline $\begin{array}{l}\text { SEBARAN MENARA TELEKOMUNIKASI SELULER } \\
\text { BERSAMA BERBASIS GIS (GEOGRAPHIC INFORMATION } \\
\text { SYSTEM) DI WILAYAH KABUPATEN LAMPUNG TENGAH }\end{array}$ & $83-89$ \\
\hline $\begin{array}{l}\text { AUTHENTIFIKASI LOGIN USER PADA PERANGKAT } \\
\text { LUNAK MENGGUNAKAN ARDUINO DAN ENKRIPSI AES } \\
256\end{array}$ & $90-95$ \\
\hline
\end{tabular}

Fakultas Ilmu Komputer

Universitas Bandar Lampung

\begin{tabular}{|c|c|c|c|c|}
\hline \multirow{2}{*}{ JMSIT } & Volume 07 & Nomor 02 & Lampung, Desember & ISSN \\
& & 2017 & $2088-5555$ \\
\hline
\end{tabular}




\section{TIM PENYUNTING}

\section{Penanggung Jawab}

Ahmad Cucus, S.Kom., M.Kom.

Ketua Tim Redaksi:

Taqwan Thamrin, ST, M.Sc.

Penyunting Ahli (Mitra Bestari):

Mustofa Usman, Ph.D (Universitas Lampung)

Dra. Wamiliana, MA., Ph.D (Universitas Lampung)

Iing Lukman, M.Sc., Ph. D (Universitas Malahayati)

\section{Penyunting:}

Fenty Ariani, S.Kom, M.Kom

Robby Yuli Endra, S.Kom.,M.Kom

Ayu Kartika Puspa, S.Kom, M.TI

Erlangga, S.Kom, M.Kom

\section{Pelaksana Teknis:}

Dian Resha Agustina, S.Kom

\section{Alamat Penerbit/Redaksi:}

Pusat Studi Teknologi Informasi

Fakultas Ilmu Komputer

Universitas Bandar Lampung

Gedung Business Center Lt.2

Jl. Zainal Abidin Pagar Alam No. 26

Bandar Lampung

Email: Journal.expert@ubl.ac.id 


\title{
OTORISASI PENGGUNA LABORATORIUM IBI DARMAJAYA BERBASIS CLIENT SERVER
}

\author{
Hendra Kurniawan ${ }^{\# 1}$, Hermanto ${ }^{* 2}$ \\ \#1*2 Program Studi Sistem Informasi \\ Fakultas Ilmu Komputer \\ Insitute Informatics And Business Darmajaya \\ Jalan Zainal Abidin Pagar Alam Bandar Lampung - Lampung - Indonesia 35142 \\ Telp. 0721 - 787214 Fax. 0721 - 700261 website : http://darmajaya.ac.id \\ ${ }^{1}$ hendra.kurniawan@darmajaya.ac.id
}

\begin{abstract}
ABSTRAK
Pembuatan user authnetication bertujuan untuk memberikan hak akses didalam penggunaan komputer pada laboratorium di IIB Darmajaya Bandar Lampung. Proses penggunaan komputer pada laboratorium dilakukan dengan melakukan registrasi dan tersimpan didalam basisdata dan data registrasi tersebut dijadikan sebagai acuan/otorisasi didalam penggunaan komputer di laboratorium IIB Darmajaya. Dengan pembuatan user authentication ini diharapkan akan meningkatkan kinerja komputer pada laboratorium dengan pembatasan hak akses atau pembatasan penggunaan oleh mahasiswa atau pihak lain yang tidak memiliki kewenangan atau tidak bertanggungjawab.
\end{abstract}

\section{Kata Kunci : Otorisasi, Pengguna Laboratorium, Client Server}

\section{PENDAHULUAN}

Teknologi di bidang komputer dewasa ini berkembang begitu pesat. Hal ini dibuktikan dengan pengguna komputer bukan hanya dari kalangan di bidang komputer saja. Namun semua kalangan dapat menikmati dan merasakan teknologi ini sebagai alat bantu pengolahan data dalam setiap aktifitasnya.

Salah satu teknologi di bidang komputer adalah teknologi basisdata, jaringan komputer dan aplikasi. Ketiga teknologi tersebut paling banyak digunakan di semua aspek kehidupan sebagai alat pengolahan data spesifik untuk membantu pekerjaan, misalnya pembuatan aplikasi inventory, pembuatan aplikasi akademik sekolah, sekolah tinggi bahkan universitas sekalipun. Teknologi tersebut memanjakan para penggunanya didalam penyimpanan data, pencarian data, sampai pada menampilkan informasi yang diperlukan secara akurat, cepat, efektif dan efisien.

Institut Informatika dan Bisnis Darmajaya disingkat IIB adalah institut yang memiliki salah satu fakultas ilmu komputer. Selain digunakan didalam proses belajar mengajar, laboratorium IIB Darmajaya juga sering digunakan untuk kegiatan dari pihak luar. Dengan padatnya aktifitas pada laboratorium IIB Darmajaya, maka diperlukan batasan pemakaian penggunaan komputer laboratorim untuk menghindari low performance komputer pada laboratorium dikarenakan adanya pengguna yang tidak terdaftar dan mampu menggunakan komputer laboratorium.
Salah satu cara untuk memberikan batasan penggunaan komputer adalah pembuatan user authentication. User authentication ini hanya akan mengizinkan pengguna yang telah terdaftar didalam basisdata pengguna laboratorium dan berbasis client server.

\subsection{Perumusan Masalah}

Berdasarkan latar belakang yang telah dipaparkan di atas, maka permasalahan dari penelitian ini adalah " Bagaimana membangun suatu aplikasi sistem manajemen user pemakaian komputer pada laboratorium IIB Darmajaya berbasis client

\subsection{Tujuan dan Manfaat}

Tujuan dan manfaat penelitian ini adalah membangun aplikasi pembuatan user authentication untuk membatasi penggunaan komputer pada laboratorium IIB Darmajaya Bandar Lampung.

\section{TINJAUAN PUSTAKA DAN LANDASAN TEORI}

2.1. Tinjauan Pustaka pada penelitian ini direferensi dari beberapa penelitian sebelumnya yaitu: 
a. Sistem Monitoring Penggunaan Laboratorium Berbasis Client-Server Studi Kasus Laboratorium Stikom Baliyang dilakukan oleh Putu Pradnya Pratistha Karya, I Made Darma Susila S.Kom., M.Kom, Ni Luh Gede Pivin Suwirmayanti S.Kom., MT

b. Penerapan Service Oriented Architecture (SOA) Dalam Proses Integrasi Sistem Informasi Inventaris Laboratorium Dan Sistem Informasi Laporan Kerusakan Komputer Pada Laboratorium STMIK Amikom yang dilakukan oleh Andika Agus Slameto

c. Aplikasi Laboratorium Komputer Kontrol Berbasis ClientServer yang dilakukan oleh Frizal Luthfi Hadyan, Doro Edi

d. Perancangan Laboratorium Komputer Menggunakan Jaringan Diskless Berbasis LTSP Dan Epoptes Sebagai Aplikasi Monitorin yang dilakukan oleh Gufron

e. Rancang Bangun Perangkat Lunak Sistem Informasi Laboratorium Fasilkom Unsri yang dilakukan oleh Muhammad M. Aris Garniardi, Mira Afrina, Hardini Novianti

\subsection{Landasan Teori}

Pembangunan sistem informasi memerlukan penyelidikan dan analisis mengenai alasan timbulnya ide atau gagasan untuk membangun dan mengembangkan sistem informasi. Analisis dilakukan untuk melihat berbagai komponen yang dipakai sistem yang sedang berjalan meliputi hardware, software, jaringan dan sumber daya manusia. Analisis juga mendokumentasikan aktivitas sistem informasi meliputi input, pemrosesan, output, penyimpanan dan pengendalian (O'Brien, 2005).

Selanjutnya melakukan studi kelayakan (feasibility study) untuk merumuskan informasi yang dibutuhkan pemakai akhir, kebutuhan sumber daya, biaya, manfaat dan kelayakan proyek yang diusulkan (Mulyanto, 2009).

Analisis kebutuhan sistem sebagai bagian dari studi awal bertujuan mengidentifikasi masalah dan kebutuhan spesifik sistem. Kebutuhan spesifik sistem adalah spesifikasi mengenai hal-hal yang akan dilakukan sistem ketika diimplementasikan (Mulyanto, 2009).

Analisis kebutuhan sistem harus mendefinisikan kebutuhan sistem yang spesifik antara lain :

1) Masukan yang diperlukan sistem

(input)

2) Keluaran yang dihasilkan (output)

3) Operasi-operasi yang dilakukan

(proses)

4) Sumber data yang ditangani

5) Pengendalian (kontrol)



Gambar 1. Spesifikasi Kebutuhan Sistem

Tahap analisis kebutuhan sistem memerlukan evaluasi untuk mengetahui kemampuan sistem dengan mendefinisikan apa yang seharusnya dapat dilakukan oleh sistem tersebut kemudian menentukan kriteria yang harus dipenuhi sistem. Beberapa kriteria yang harus dipenuhi adalah pencapaian tujuan, kecepatan, biaya, kualitas informasi yang dihasilkan, efisiensi dan produktivitas, ketelitian dan validitas dan kehandalan atau reliabilitas (Mulyanto, 2009).

\subsection{Perangkat Lunak Pendukung}

Untuk membuat sistem informasi yang berbasis komputer tentu memerlukan perangkat lunak yang berfungsi sebagai pendukung pembuatan sistem informasi yang berbasis komputer tersebut. Adapun perangkat lunak pendukung yang digunakan penulis adalah Microsoft Visual Basic 6.0 dan SQL Server 2000.

\subsubsection{Microsoft Visual Basic 6.0}

Microsoft Visual Basic 6.0 merupakan salah satu dari bahasa pemograman visual yang saat ini banyak digunakan oleh programer baik pemula ataupun yang sudah mahir untuk membuat suatu program aplikasi karena penggunaan relatif lebih mudah dibandingkan bahasa non-visual misalnya seperti pascal, java, dan lain-lain.

\subsection{2. $S Q L$ Server}

Microsoft SQL server 2000 adalah Sistem manajemen basis data yang memakai perintah Transact-SQL untuk mengirim perintah dari Komputer client ke Komputer server. Microsoft SQL Server 2000 dapat dijalankan pada NT 4.0 Server atau Microsoft Windows 2000 Server, selain itu dapat pula di install pada personal desktop di Windows 2000 Profesional, Windows 98 Milenium. Sistem akan dipergunakan oleh beberapa komputer (client-server) maka database yang dibangun adalah merupakan database yang berfungsi untuk menunjang hal tersebut untuk itu dalam penulisan ini dipakai database Microsoft SQL Server 2000, selain itu database ini juga compatible dengan bahasa pemrograman yang digunakan. Secara teoritis, program $S Q L$ yang sudah terinstall pada komputer dapat menampung 32.767 database dan terdapat lebih dari 2 billion objek. 
SQL Server adalah sistem manajemen database relasional (RDBMS) yang dirancang untuk aplikasi dengan arsitektur client/server. Istilah client, server, dan client/server dapat digunakan untuk merujuk kepada konsep yang sangat umum atau hal yang spesifik dari perangkat keras atau perangkat lunak. Pada level yang sangat umum, sebuah client adalah setiap komponen dari sebuah sistem yang meminta layanan atau sumber daya (resource) dari komponen sistem lainnya. Sedangkan sebuah server adaah setiap komponen sistem yang menyediakan layanan atau sumber daya ke komponen sistem lainnya.

Sistem client/server adalah dirancang untuk memisah layanan basisdata dari client, dengan penghubungnya menggunakan jalur komunikasi data. Layanan basisdata diimplementasikan pada sebuah komputer yang berdaya guna, yang memungkinkan manajeman tersentralisasi, keamanan, dan berbagai sumber daya. Oleh karena itu, server dalam client/server adalah basisdata dan layanannya. Aplikasi-aplikasi client diimplementasikan pada berbagai flatform, menggunakan berbagai kakas pemrograman.

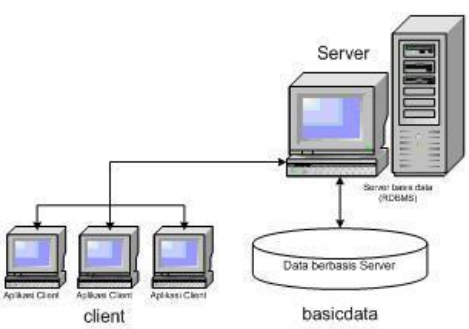

Gambar 2. Sistem Client /Server (Marcus Teddy cs 2004)

SQL Server menggunakan tipe dari database yang disebut database relasional. Database relasional adalah database yang digunakan sebuah data untuk mengatur atau mengorganisasikan kedalam tabel. Tabel-tabel adalah alat bantu untuk mengatur atau mengelompokan data mengenai subyek yang sama dan mengandung informasi dan kolom dan baris. Tabel-tabel saling berhubungan dengan mesin database ketika dibutuhkan.

SQL Server mendukung beberapa tipe data yang berbeda, termasuk untuk karakter, angga, tanggal (datetime) dan uang (money), SQL Server digunakan untuk menggambarkan model dan implementasi pada database.

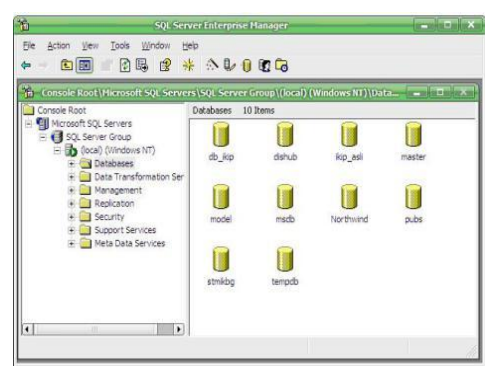

Gambar 4.

Tampilan Microsoft SQL Server 2000

\section{METODOLOGI PENELITIAN}

\subsection{Bahan Penelitian}

Data yang digunakan dan dibutuhkan dalam penelitian ini adalah jadwal perkuliahan di Institut Informatika dan Bisnis (IIB) Darmajaya. Adapun lokasi penelitian dibagian laboratorium di IIB Darmajaya Bandar Lampung. Pengumpulan data ini berfungsi untuk pembuatan aplikasi otorisasi penggunaan laboratorium berbasis Client Server. Adapun jenis data yang akan digunakan dalam penelitian ini terdiri dari:

1. Data Primer

Yaitu data berupa data jadwal perkuliahan di IIB Darmajaya.

2. Data sekunder

Merupakan data yang telah tersedia yang dapat digunakan sebagai pendukung dalam pemodelan aplikasi otorisasi pengguna laboratorium yaitu pengelolaan data kesiapan laboratorium. Data sekunder ini juga diperoleh melalui studi pustaka.

\subsection{Alat Penelitian}

Aplikasi pengguna laboratorium ini dapat digunakan sebagai alat untuk efisiensi penggunaan laboratorium berdasarkan jadwal perkuliahan yang ada.Sedangkan pengujian aplikasi digunakan alat bantu komputer dengan sistem operasi, Windows $X p, \quad M y S Q L$ untuk perancangan database dan bahasa pemrograman Visual Basic.

\subsection{Kerangka Penelitian}

Metode pengembangan sistem System Development Life Cycle (SDLC) dengan tingkatan arsitektur yang dimulai dengan tingkat konseptual hingga detail rancangan, adapun tahapannya dapat dilihat pada Gambar 5 berikut: 


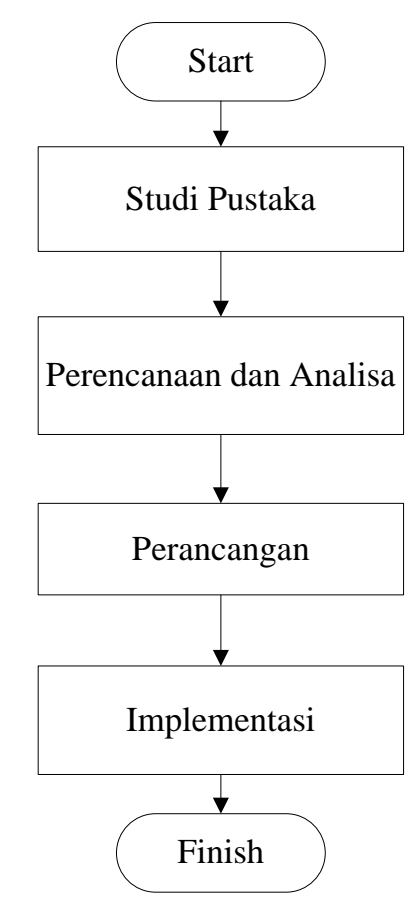

Gambar 5. Kerangka Penelitian

\subsection{Studi Pustaka}

Studi pustaka merupakan studi literatur dilakukan dengan pencarian data dan informasi tentang aplikasi otorisasi pengguna laboratorium, terapan terapan terkini, penelitian dan pengembangan yang telah dilakukan. Merupakan bahan yang akan digunakan sebagai pedoman dalam penelitian yaitu: a. Mempelajari desain database penjadwalan perkuliahan yang ada di IIB Darmajaya.

b. Mempelajari beberapa literatur jurnal yang berkaitan dengan Aplikasi yang akan dibuat.

c. Mempelajari metode pengembangan sistem System Development Life Cycle (SDLC) sebagai metode dalam pemodelan Aplikasi Otorisasi Pengguna Laboratorium.

Studi pustaka dilakukan terus selama penelitian untuk mendapatkan informasi terbaru dan perbaikan yang mungkin dilakukan.

\subsection{Perencanaan}

Perancangan aplikasi otorisasi pengguna laboratorium merupakan bentuk desain dalam merekomendasikan solusi dalam membatasi akses pengguna pada penggunaan laboratorium. Perancangan aplikasi otorisasi pengguna laboratorium dapat dilihat pada gambar 6

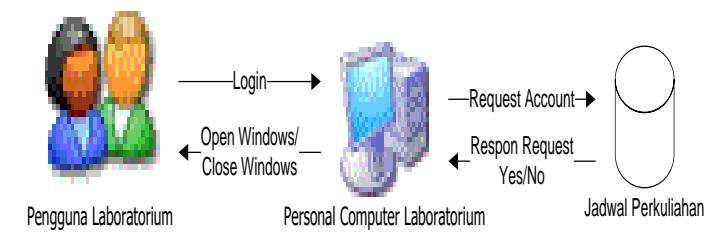

Gambar 6. Perancangan Aplikasi

\section{PEMBAHASAN 4.1 Implementasi Sistem}

Hasil penelitian ini adalah aplikasi otorisasi pengguna laboratorium aplikasi untuk membatasi pengguna laboratorium bagi pengguna yang tidak terdaftar pada laboratorium yang akan digunakan. Apalikasi ini dietakkan pada laboratorium yang dihubungkan secara terintegrasi dengan database IIB Darmajaya. Aplikasi ini menggunakan database IIB Darmajaya terutama menghubungkan dengan tabel jadwal perkuliahan yang dimana tabel tersebut dijadikan sebagai parameter didalam akses penggunaan laboratorium.

Setelah perancangan selesai, kemudian melakukan pembangunan aplikasi, instalasi dan rencana pemeliharaan. Dengan tujuan aplikasi terintegrasi untuk aplikasi dapat terus digunakan sesuai kebutuhan dan informasi yang diharapkan. Pada aplikasi terdapat menu login admin seperti pada gambar 7.



Gambar 7. Login Akses Pengguna Laborotorium berdasarkan jadwal perkuliahan

Untuk lebih jelasnya akan dijelaskan sebagai berikut: Masukkan User (NPM) dan Password, sesuai dengan di database, seperti pada gambar dibawah ini:

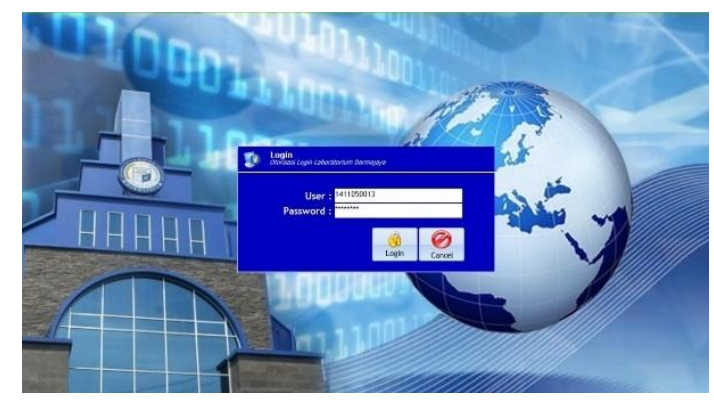

Gambar 8. Masukkan Username dan Password

Jika Login Valid, maka akan Muncul Info, sekaligus Update di Presensi Mahasiswa, menjadi Masuk sesuai dengan Matakuliah dan Kelas. Seperti pada gambar dibawah ini: 




Gambar 9. Username dan Pasword Valid

Setelah Login Valid, maka akan muncul Info dan Pengumuman dari Kampus. Seperti pada gambar dibawah ini.



Gambar 10. Tampilan Halaman Info dan Pengumuman dari Kampus

Kemudian langsung muncul halaman Logout, seperti gambar di bawah ini:

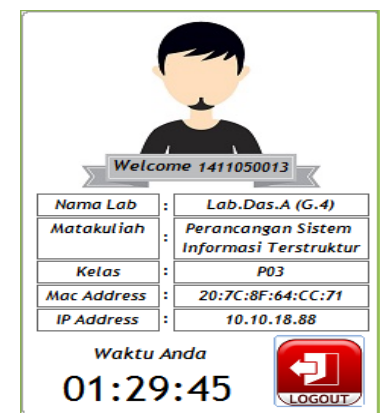

Gambar 11. Log Out

Jika LoginInvalid, maka akan muncul info seperti di bawah ini:

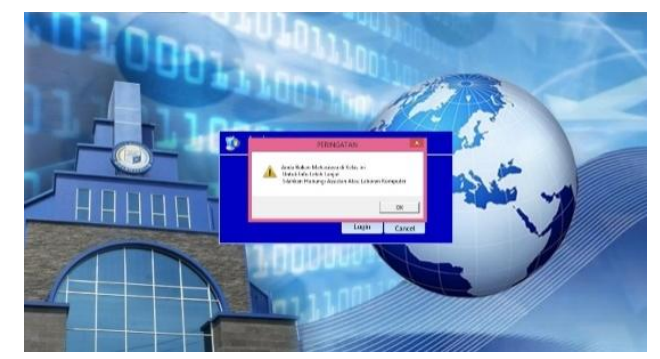

Gambar 12. InvalidUsername dan Password

\section{KESIMPULAN DAN SARAN 5.1 Kesimpulan}

Kesimpulan yang bisa disampaikan pada penelitian ini adalah sebagai berikut:

1. Penelitian ini dibuat untuk membatasi penggunaan laboratorium oleh pengguna dengan menghubungkan penggunaan laboratorium dengan jadwal perkuliahan pada semester tertentu.

2. Penelitian ini telah melalui proses penerapan dengan mengkomunikasi aplikasi pada database IIB Darmajaya yang meliputi: mahasiswa, matakuliah, ruang/kelas dan jadwal perkuliahan.

\subsection{Saran}

Kedepannya akan dibangunkan sistem berbasis Android yang dapat diakses dengan mudah oleh pihak pengguna yang memiliki kewenangan

\section{Daftar Pustaka}

[1] Andika Agus Slameto, Penerapan Service Oriented Architecture (Soa) Dalam Proses Integrasi Sistem Informasi Inventaris Laboratorium Dan Sistem Informasi Laporan Kerusakan Komputer Pada Laboratorium Stmik Amikom

[2] Frizal Luthfi Hadyan, Doro Edi, Penerapan Aplikasi Laboratorium Komputer Kontrol Berbasis ClientServer

[3] Gufron, Perancangan Laboratorium Komputer Menggunakan JaringanDiskless Berbasis Ltsp Dan Epoptes

[4] Marcus, Teddy, 2004, Delphi Developer Dan SQL Server 2000, Informatika, Bandung.

[5] Muhammad M. Aris Garniardi, Mira Afrina, Hardini Novianti, Rancang Bangun Perangkat Lunak Sistem Informasi Laboratorium Fasilkom Unsri

[6] Mulyanto, Agus. (2009). Sistem Informasi Konsep dan Aplikasi. Pustaka

[7] O'Brien, James. A. (2005). Introduction to Information System. 12th Edition. McGraw. Hill Companies Inc., New York

[8] Putu Pradnya Pratistha Karya, I Made Darma Susila S.Kom., M.Kom, Ni Luh Gede Pivin Suwirmayanti S.Kom., MT Sistem Monitoring Penggunaan Laboratorium Berbasis ClientServer Studi Kasus Laboratorium Stikom Bali 


\title{
Template Penulisan Jurnal Expert
}

\author{
First Author ${ }^{\# 1}$, Second Author ${ }^{* 2}$, Third Author ${ }^{\# 3}$ \\ ${ }^{\#}$ First-Third Department, First-Third University \\ Address Including Country Name \\ ${ }^{1}$ first.authorefirst-third.edu \\ ${ }^{3}$ third.authorefirst-third.edu \\ *Second Company \\ Address Including Country Name \\ ${ }^{2}$ second. authoresecond. com
}

\section{Abstrak}

Abstrak dalam bahasa Indonesia ditulis dengan rata kiri-kanan, dengan satu spasi dan satu kolom. Kata "Abstrak" sebagai judul ditulis dalam huruf Times 11-point, tebal, rata tengah, dengan huruf pertama dikapitalkan. Teks abstrak ditulis dengan huruf Times 10-point, satu spasi, sampai lebih kurang 150 kata. Sesudah abstrak tuliskan kata kunci dari makalah tersebut dalam daftar kata kunci. Kemudian dilanjutkan dengan teks utama makalah.

Kata kunci : : kata kunci abstrak

\section{Pendahuluan}

Semua makalah ditulis dalam bahasa Indonesia. Panduan penlisian ini dilengkapi dengan deskripsi huruf, spasi, dan informasi lainnya yang berhubungan dengan penulisan makalah anda. Diharapkan semua penulis dapat mengikuti template yang disediakan dan jika terdapat pertanyaan, silahkan menghubungi editor jurnal EXPERT di journal.expert@ubl.ac.id atau telefon +62721774626 .

\section{Format penulisan}

Materi yang akan dicetak, meliputi teks, gambar ilustrasi, dan grafik harus berada dalam area pencetakan yaitu bidang kertas A4 dengan margin 2.5 $\mathrm{cm}$ di semua sisi kertas. Jangan menuliskan atau meletakkan sesuatu diluar bidang cetak tersebut Seluruh teks ditulis dalam format dua kolom dengan lebar kolom $7.5 \mathrm{~cm}$ dan jarak antar kolom $1 \mathrm{~cm}$, kecuali bagian abstrak yang dituliskan dalam format satu kolom. Seluruh teks harus rata kiri-kanan.

Template ini menggunakan format yang dianjurkan. Untuk mempermudah penulis dalam memformat makalah/jurnalnya, format ini dapat digunakan sebagai petunjuk atau format dasar penulisan.

\section{Judul utama}

Judul utama (pada halaman pertama) harus dituliskan dengan jarak margin $2 \mathrm{~cm}$ dari tepi kertas, rata tengah dan dalam huruf Times 14-point, tebal, dengan huruf kapital pada huruf pertama dari kata benda, kata ganti benda, kata kerja, kata sifat, dan kata keterangan; jangan menggunakan huruf kapital pada kata sandang, kata hubung, terkecuali jika judul dimulai dengan kata-kata tersebut. Sisakan satu 11point baris kosong sesudah judul.

\section{Nama penulis dan afiliasi}

Nama penulis dan afiliasi diletakkan ditengah dibawah judul dan dituliskan dengan huruf Times 11point, tidak tebal. Afiliasi dan email penulis dituliskan dibawahnya dengan huruf Times 10-point, miring. Penulis yang lebih dari satu orang dituliskan dalam dua atau tiga kolom, dengan afiliasi dan email masingmasing.

\section{Tipe huruf}

Huruf yang digunakan adalah turunan dari huruf Times, meliputi Times Roman atau Times New Roman. Jika tipe huruf tersebut didak tersedia pada aplikasi pengolah kata yang digunakan, usahakan untuk memilih huruf yang memiliki kemiripan sedekat mungkin dengan Times. Hindari penggunaan huruf bit-mapped. Diharapkan untuk menggunakan huruf-huruf True-type 1.

\section{Teks utama}

Ketik teks utama dengan menggunakan huruf Times 10-point, satu spasi. Jangan menggunakan dua spasi. Setiap paragraf sebaiknya memiliki panjang lebih kurang $0.5 \mathrm{~cm}$. Pastikan teks ditulis dengan rata kiri-kanan. Jangan menambahkan baris kosong di antara paragraf. Istilah dalam bahasa asing (foreign language) yang tidak dapat diterjemahkan dalam bahasa utama makalah harus dituliskan dalam huruf miring.

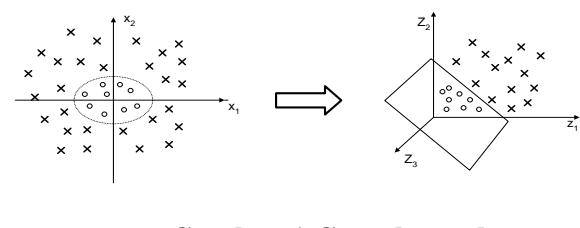

\section{Gambar 1 Contoh gambar}

Keterangan gambar dan tabel dituliskan dengan huruf Times 9-point. Sedangkan pengacuan gambar pada teks menggunakan huruf Times 10-pont. Keterangan gambar diletakkan di bawah, tengah gambar yang dijelaskan. Keterangan tabel diletakkan sebelum tabel dengan rata kiri.

Uraian yang dalam bentuk list (bulleted) dituliskan untuk:

- Uraian yang tidak memiliki aturan pengurutan tertentu

- Uraian yang tidak terikat antara uraian yang satu dan lainnya 


\begin{tabular}{|l|l|l|}
\hline No. & Jumlah & Kecepatan \\
\hline 1. & 25 & $10 \mathrm{~s}$ \\
\hline 2. & 50 & $15 \mathrm{~s}$ \\
\hline
\end{tabular}

Sedangkan untuk uraian yang berurutan dituliskan dengan penanda huruf, untuk:

a. Uraian yang memiliki aturan pengurutan

b. Uraian yang terkait dengan uraian lainnya

c. Uraian yang setiap itemnya akan diacu pada tulisan utama

\section{Judul pertama}

Sebagai contoh, "1. Pendahuluan", dituliskan dalam huruf Times 11-point, tebal, huruf pertama kata pertama ditulis dengan huruf kapital. Gunakan tanda titik (".") sesudah nomor judul.

\subsection{Judul kedua}

Sebagaimana judul pertama, judul kedua dituliskan dengan huruf Times 11-point, tebal. Nomor judul terdiri dari dua angka yang dibatasi dengan tanda titik. Tidak ada titik sesudah nomor judul dengan teks judul.

\subsubsection{Judul ketiga}

Untuk uraian yang lebih panjang dan tidak dapat dituliskan dalam bentuk uraian terurut, digunakan judul ketiga. Judul ketiga menggunakan ukuran huruf yang lebih kecil dari judul pertama dan judul kedua yaitu huruf Times 10-point, tebal. Nomor judul terdiri dari tiga angka yang dibatasi dengan tanda titik. Tidak ada titik sesudah nomor judul dengan teks judul.

\section{Catatan kaki}

Penggunaan catatan kaki dimaksudkan untuk membatu pembaca memperoleh penjelasan terhadap kalimat dalam teks tulisan utama. Catatan kaki dituliskan pada bagian bawah kolom yang memuat acuan ke catatan kaki tersebut. Catatan kaki ditulis dengan huruf Times 8-point, satu spasi. Hindari penggunaan banyak catatan kaki.

\section{Pemrograman}

Listing program dan disain algoritma dituliskan dengan menggunakan huruf dengan lebar yang tetap seperti Courier New 9-point.

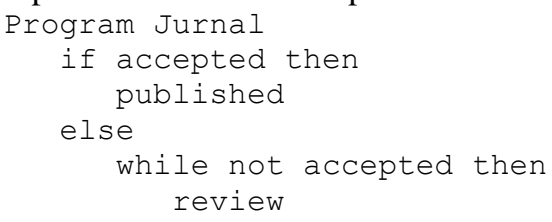

Sedangkan notasi matematika dituliskan dengan menggunakan simbol notasi yang sesuai.

\section{Daftar pustaka}

Daftar pustaka memuat daftar bacaan yang diacu dalam tulisan utama. Daftar pustaka ditulis dengan metode penulisan kepustakaan APA (American Psychological Association) Style, dengan huruf Times 10 -point. Kutipan dalam teks utama yang mengacu kepada daftar pustaka dituliskan dengan angka dalam kurung siku [nama penulis, tahun].

[1] A.B. Smith, C.D. Jones, and E.F. Roberts, Article Title, "Journal", Publisher, Location, Date, Years, pp. 1-10.

[2] Jones, C.D., A.B. Smith, and E.F. Roberts, Book Title, Publisher, Location, Date.

[3] S. Zhang, C. Zhu, J. K. O. Sin, and P. K. T. Mok, "A novel ultrathin elevated channel lowtemperature poly-Si TFT," IEEE Electron Device Lett., vol. 20, pp. 569-571, Nov. 2016. 
Redaksi :

Pusat Studi Teknologi Informasi (PSTI). Gedung Business Center Lt 2 J. Zainal Abidin No. 26 Bandar Lampung Telp. 0721 - 774626 9 772088 " 555000

SistemInformasi@ubl.ac.id 